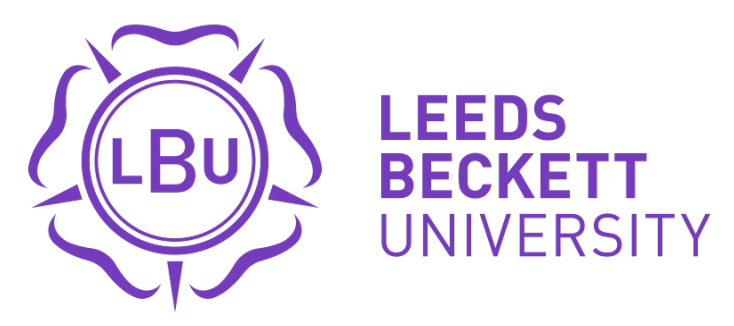

Citation:

Huynh, TLD and $\mathrm{Wu}, \mathrm{J}$ and Duong, AT (2019) Information Asymmetry and firm value : Is Vietnam different? Journal of Economic Asymmetries, 21. ISSN 1703-4949 DOI: https://doi.org/10.1016/j.jeca.2019.e00147

Link to Leeds Beckett Repository record:

https://eprints.leedsbeckett.ac.uk/id/eprint/6527/

Document Version:

Article (Accepted Version)

Creative Commons: Attribution-Noncommercial-No Derivative Works 4.0

The aim of the Leeds Beckett Repository is to provide open access to our research, as required by funder policies and permitted by publishers and copyright law.

The Leeds Beckett repository holds a wide range of publications, each of which has been checked for copyright and the relevant embargo period has been applied by the Research Services team.

We operate on a standard take-down policy. If you are the author or publisher of an output and you would like it removed from the repository, please contact us and we will investigate on a case-by-case basis.

Each thesis in the repository has been cleared where necessary by the author for third party copyright. If you would like a thesis to be removed from the repository or believe there is an issue with copyright, please contact us on openaccess@leedsbeckett.ac.uk and we will investigate on a case-by-case basis. 


\title{
Information Asymmetry and firm value: Is Vietnam different? ${ }^{1}$
}

\author{
Toan Luu Duc Huynh² \\ Junjie $\mathbf{W u}^{3}$ \\ An Trong Duong 4
}

\begin{abstract}
Using firm-level data from 250 non-financial companies with 2,500 firm-year observations collecting from two stock exchange markets in Vietnam covering a 10-year period from 2008 to 2017, this paper examines the relationship between information asymmetry and firm value in Vietnamese firms. The findings reveal that fundamentally, information asymmetry in Vietnamese firms has a negative impact on firm value. Although this conclusion is consistent with that in the literature underlying by pecking order and agency cost theories, the value of information asymmetry related variables is higher than that in similar studies conducted in other developed countries. The results also find that the financial leverage in Vietnamese firms is higher than in other developed countries but can only play a limited role in mitigating the negative impact of information asymmetry on firm value. All in all, the findings relating to all variables used in the study highlight that Vietnam is a typical emerging country because there is a clear distance with other developed countries.
\end{abstract}

Keywords: Information Asymmetry, firm value, leverage, Vietnam, GMM

JEL Classification: H20; H50; H70; G38

\footnotetext{
1 This paper was accepted in International Conference on Business and Finance 2019 - Ho Chi Minh City (Vietnam) and this research is fully funded by University of Economics Ho Chi Minh City.

${ }^{2}$ School of Banking, University of Economics Ho Chi Minh City, Vietnam. Email: toanhld@ueh.edu.vn

${ }^{3}$ Leeds Business School, Leeds Beckett University. Email: J.Wu@leedsbeckett.ac.uk

${ }^{4}$ Banking University of Ho Chi Minh City, Vietnam
} 


\section{Introduction}

Obtaining appropriate and accurate information is considered by investors as the most important precondition to make an investment decision, and thus the power of information is defined as the assumption for an efficient market. However, asymmetric information rather than information efficiency has been commonly observed in many markets. Akerlof's pioneering work (1970) first defines the concept of information asymmetry and demonstrates in a market where sellers hold better information than buyers about the quality of products which can cause an adverse selection of low-quality products. Spence (1973) and Stiglitz (1974) late to further develop the concept, leading the three jointly won the Nobel Prize in 2001.

Information asymmetry is thought of as a kind of market failure. When it exists, it not only affects the market value as a whole but also the value of the firms listed in the stock market. This is because information asymmetry could lead to individual investors and firms making wrong financial decisions with loss of their investment and the share value of firms. For example, firms with good wealth and large profits normally tend to use own recourse to finance business and avoid a large chunk of debts (Besbes and Boujelbene, 2014). However, if under the exposure of asymmetric information, the pecking order theory suggests that firms prefer an order of debt financing to the equities in order to reduce information risk (Myers and Majluf 1984; Agarwal and O'Hara, (2007). Myers and Majluf (1984) point out that once a market cannot distinguish good or bad quality investment opportunities, firms in favourable positions often choose self-financing. These examples demonstrate information symmetry/asymmetry is an important factor in determining firms' capital structure, investment decision and consequently firm value.

Scholars have examined the linkages of market information asymmetry level, firm asset level, leverage level and firm value/performance (see examples, Botosan, 1997; D'Mello and Ferris, 2000; D'Mello et al., 2008; Bharath et al., 2009; Drobetz et al., 2010; Fosu, 2013; He et al., 2013; Gao and Zhu, 2015; Focu et al., 2016). From these studies, readers understand how information asymmetry impacts firms in developed countries such as the US (Botosan, 1997; D'Mello and Ferris, 2000; D'Mello et al., 2008; Bharath et al., 2009), the UK (Focu et al., 2016), Australia (He et al., 2013), other developing countries such as South Africa (He et al., 2013) or across different countries (Drobetz et al., 2010; Gao and Zhu, 2015). However, less evidence 
found in the literature relating to the relationship between information asymmetry, leverage level and firm value in Vietnam. Vietnam is an emerging country in South-East Asia with rapid development in recent decades and is also in the process of transforming from a traditional socialist economy to a market economy. It thus can be reasonably predicted that there should have some different characteristics in terms of the relationship between information asymmetry, leverage level and firm value, compared to that in other developed countries or other developing countries in different geographical regions.

To develop an understanding of the difference of this topic in the Vietnamese context, this paper aims to examine the relationship between information asymmetry and firm value in Vietnamese listed firms. In order to carry out a reasonable comparison, this study purposely is designed to adopt similar methodology used by Fosu et al. (2016) in the UK to capture a rough distance/feature between a developing country and a developed nation. Our firm-level data include 250 non-financial companies with 2,500 firm-year observations collecting from two stock exchange markets in Vietnam covering a 10-year period from 2008 to 2017. Least squares based on Pooled OLS ((Pooded Ordinary Least Square), Fixed-Effect Model (FEM) and Random-Effect Model (REM), GMM one step (one-step generalized method of moments) are employed to analyse data. The findings report that there are a number of differences regarding the research variables used and a clear distance that Vietnam is behind the UK, though a negative impact of information asymmetry on firm value is observed in both countries.

The rest of the paper is structured as follow: section 2 develops hypotheses based on theoretical reasoning, section 3 explains the methods used in the study, section 4 presents results, and section 5 makes a final conclusion.

\section{Theoretical reasoning and hypothesis formulation}

The concept of information asymmetry was created from the study of The Market for Lemons' theory (Akerlof, 1970) which originally refers to product buyers have less information about product quality they bought than the sellers. Since then, a number of influential theories relating to information asymmetry have been developed, such as Signalling Theory by Spence (1973) and Stiglitz (1974) and Pecking Order Theory (POT) by Myers (1984) and Myers and Majluf (1984). POT specifically suggests that the management (agent) inside a company has better information about the firm's actual value than outside shareholders (principal). As such, the 
cost of adverse selection arising from information asymmetry leads to the priority of using debt financing rather than equity financing (Myers and Majluf, 1984). Afterwards, many scholars have provided theoretical arguments and empirical evidence to support POT. For example, the research of Botosan et al. (1997) evaluates the cost of equity and find it has a strong connection with firm value. A study from Ryen et al. (1997) is considered as the further development of the information asymmetry and its relationship related to investment decisions as well as firm valuation. This research proves that insiders of a firm have more information than outside investors leading to newly issued shares undervalued. In addition, Dierkens (1991) demonstrate that at the time of issuing equity, the extent of information asymmetry is relatively low, however, it increases alongside the distribution of predictions of the capital cost by analysts. Furthermore, the relationships among information asymmetry and higher equity cost (Dierkens, 1991 and Botosan, 1997), high levels of financial leverage (Bharath et al., 2009; Gao and Zhu, 2015; Fosu et al. 2016) and lower value of cash have been researched. Importantly, Drobetz et al. (2010) emphasize the role of free cash flow under the condition of asymmetric information. Then based on the idea in Drobetz et al. (2010), Fosu et al. (2016, p.141) further develop the research argument by "conditioning the relationship between firm value and information asymmetry on firms' level of financial leverage". In a similar vein, Drobetz et al. (2010) remarkably indicate the calculation methods and employing quantitative techniques for measuring variables can convey asymmetric information. This study uses the dispersion of analysts' forecasts and error in analysts' forecasts as the main measurements of information asymmetry and Fosu et al. (2016) also follow these measures.

\subsection{The impact of information asymmetry on firm value}

As discussed above, how a firm makes its capital structure choice and investment decision are debated and studied by many scholars. A well-known theory to explain this is Pecking Order Theory established by Myers (1984), and Myers and Majluf (1984). POT not only highlights the decision-making process of whether a firm opts issuing equity capital or debt financing in the environment of information asymmetry, but also the consequence of costs of the firm's value because of the decision. As we know, for a principal-agent problem, managers of firms often hold more information about the firm's performance, asset value and prosperity than the investors (shareholders). In other words, information about the firm hold by insiders and outsiders are asymmetric. According to the POT, in a firm with a higher degree of information asymmetry, managers are more realistic and more likely to propose newly issued equity capital under-priced (Fosu et al., 2016), and they also tend to invest in projects having potentially 
positive NPV (Myers, 1984). However, shareholders in the firm do not have the same level of information and cannot agree with the decision of the managers. As such, they are more likely to reject these projects with potentially positive NPV because the under-pricing equities diluted their investment wealth. Consequently, the firm would lose good investment opportunities (i.e. resources are misallocated) and firm value would be reduced (Myers and Majluf, 1984). Therefore, information asymmetry is costly to firms because of adversely selecting cost which prevents the firms to opt cheap financing and consequently reduces the firm value (Fosu et al., 2016).

Myers and Majluf's POT has been empirically proved by many studies in other countries, and examples include Dierkens (1991), Ryen et al. (1997), Botosan (1997), Bharath et al. (2008), Drobetz et al. (2010), Fauver and Naranjo (2010), Gao and Zhu (2015) and Fosu et al. (2016). The principle of information asymmetry in Vietnamese firms are the same, though Vietnam is still classified as an emerging market. We thus have our first hypothesis formulated as:

H1: Information asymmetry in Vietnamese firms is negatively correlated with firm value.

\subsection{The role of financial leverage between information asymmetry and firm value}

POT has another assumption that financial leverage (i.e. debt financing) can help firms mitigate the adversely selected costs caused by information asymmetry (Fosu et al., 2016). This is because, for a firm, external equity capital is the most information-sensitive security compared to debt financing. When managers in a firm have superior information about the firm than the firm owners (investors), they would prefer (if possible) issuing less information-sensitive security (i.e. opting debt financing) over equity capital, once the firm requires external financing (Myers and Majluf, 1984). The reason behind this is because issuing new stock/share will involve future dividend pay-out whereas dividend payout ratios are quite sticky (Myers, 1984). In other words, the firm's leverage has played an important role in its information asymmetry and firm value.

A significant number of studies provide empirical evidence to support the assumption. Among them, earlier research includes, for example, Ryen et al. (1997), Grossman and Hart (1982) and Opler and Titman (1994), as well as recent articles of Bharath et al. (2009), Gao and Zhu (2015) and Fosu et al. (2016). The findings from these studies are generally consistent and confirm 
prioritising debt financing over issuing external equity and keeping healthy cash flow are effective ways of reducing information asymmetry and generating firm value (Fosu et al., 2016). Similarly, the principle should be applied in Vietnamese companies, and we thus expect our second hypothesis expressed as:

H2: Financial leverage in Vietnamese firms can reduce the negative impact of information asymmetry on firm value.

\section{Methods}

\subsection{Sample}

To test our hypotheses developed in the last section, we firstly collect listing companies in the two stock exchange markets in Vietnam (i.e. HOSE and HNX). As of December 26, 2016, there were 699 firms on the list. ${ }^{1}$ Followed a standard practice proposed by other scholars (e.g. Gao and Zhu, 2015; Fosu et al., 2016), financial and utility companies are excluded because their businesses can be more likely influenced by government's policies and regulations. We then visit relevant websites ${ }^{2}$ to collect individual companies' financial data. Additional criteria are applied to maintain data quality. For example, we drop the firms from the sample if (1) their financial statements are not disclosed following accounting standard, (2) the companies with negative equity; and (3) the firms with missing values for three consecutive firm-year observations. In this case, our final firm-level data include 2,500 firm-year observations (i.e. yearly data for 250 firms) $)^{3}$ and the investigation period is 10-year long from 2008 to 2017.

\subsection{Information asymmetry measurement}

By referring the work done by Krishnaswami and Subramaniam (1999), Drobetz et al. (2010) and Fosu et al. (2016), we use the dispersion of analysts' forecasts (Asy-Disp) and analysts' forecast error $(A s y-E r)$ as the main measures of information asymmetry in order to examine its relationship with firm value.

\footnotetext{
${ }^{1}$ https://vietstock.vn/2017/01/chuyen-niem-yet-2016-it-nhung-dinh-dam-741-512080.htm

${ }^{2}$ Such as, http://cafef.vn/; https://www.cophieu68.vn/export.php; https://www.stockbiz.vn/CompanyAZ.aspx?Alphabet=P.

${ }^{3} \mathrm{~A}$ list of sample firms is available upon request.
} 
The dispersion of analysts' forecasts $(A s y$-Disp) is the standard deviation of analysts forecast about earning per share (EPS) of the fiscal year. It is expected a higher level of dispersion represents a higher level of information asymmetry (Krishnaswami.et al., 1999; Drobetz et al., 2010). According to Fosu et al. (2016), the dispersion of analysts' forecasts can be expressed as:

$$
\text { Asy-Disp }=\ln \left(1+\frac{\text { St.d analysts forecast } E P S}{\mid \text { Median forecast } E P S \mid}\right)
$$

The error of analysts forecast $(A s y-E r)$ is the difference between the forecast of analysts earnings per share and the actual earnings per share for the fiscal year (Krishnaswami et al., 1999; Drobetz et al., 2010). A higher level of error forecast suggests a higher level of asymmetric information. For each fiscal year, the latest forecast has been used to make sure the representativeness of the forecast at the year-end. Besides, to ensure the comparability across sample companies relating to the asymmetric information measures, we have adjusted to the median forecast of analysts in the fiscal year (Drobetz et al., 2010; Fosu et al., 2016). The error of analysts forecast (Asy-Er) can be formulated as:

$$
\text { Asy-Er }=\operatorname{Ln}\left(1+\frac{\mid E P S_{\text {forecast }-E P S_{\text {actual }} \mid}}{\mid \text { median } E P S \mid}\right)
$$

EPS forecast is an important value used by the authors to estimate the calculation of Asy variables for model testing in this paper. EPS forecast is calculated by using the previous year's EPS results and combined with EPS (g) growth through ROE and retained rate of return, parameters collected and processed from information asymmetry published. For example, to calculate the EPS forecast for year N, the actual EPS of N-1 year is used, the ROE value in year $\mathrm{N}-1$ is $\mathrm{b}$ and the $\mathrm{N}-1$ retained rate is $\mathrm{C}$, then the calculated result is $\mathrm{a} *(1+(\mathrm{b} * \mathrm{c}))$.

The third measure of information asymmetry (Asy-Dummy) is used. It is a dummy variable: 1 representing if the dispersion of analysts is larger than the median forecast in the industry; 0 otherwise. Using this additional measure is because according to Fosu et al. (2016), it can effectively capture companies which have higher information asymmetry compared to their peers in the same sector. The sectors in our sample have also followed the classification of 
Industry Classification Benchmark (ICB) which include: Oil and Gas, basic materials, industrials, consumer goods, consumer services, telecommunication, and technology.

Asy- Disp is considered as the deviation of the forecast and Asy - Dummy is a variable set to determine the dispersal deviation, therefore. If Asy - Disp is bigger than the estimated value of Asy - Disp's average during years of study, the value is " 1 "; if all the predictions have the deviation reversed, the value is "0". However, according to Drobetz (2010) and Fosu et al. (2016), the meaning of Asy - Dummy is considered as a forecasted result by at least two forecasters of the company. Because predicting is difficult, the authors use the accepting value of conclusion to give the numbers in a variable set of Asy - Dummy.

\subsection{Firm value measurement and control variables}

The firm value (Value) is measured as the ratio of the market value of assets to book value of assets as in Muray and Pajuste (2005). The market value of assets is measured by the number of outstanding shares. This is the critical value (the dependent variable) in our research model. The relationship between a firm's leverage to the firm's value is also key for the study. We thus consider firms' leverage as another key variable. Leverage ( $L E V)$ is the ratio of the book value of debts to book value of assets. The adoption of book value is to reduce the potential reverse causation from firm value to leverage (Opler and Titman, 1994; Fosu et al., 2016).

We further control for a number of variables not included in the hypotheses which consist of firm size, tangible assets and sales growth followed Muray and Pajuste (2005) and Fosu et al. (2016). Firm size (Size) is measured as the natural logarithm of the book value of total assets. According to Maury and Pajuste (2005), when firms tend to larger and mature, their valuation would be lower. It is therefore that we can expect a negative relationship between firm size and firm value. Tangible assets (Tang) is measured as the ratio of tangible assets to total assets. Firms with a significant proportion of tangible assets have less value generated from intangible assets (for example human capital) (Muray and Pajuste, 2005). This argument indicates a negative relationship between tangible asset and firm value. However, on the other hand, firms with more tangible assets might be less asymmetric information and more values generated. As such the expected effect of tangible assets on firm value is still unclear. Sale Growth (Growth) is the annual growth rate of a firm' sales which is expressed by fractions. A positive 
relationship between sale growth and firm value is expected because firms with high growth are turned to having higher valuation (Muray and Pajuste, 2005).

In Table 1, the variables used in the study and their expected prediction are summarised.

\section{Insert Table 1 here}

\subsection{Analytic model}

In this sub-section, we introduce the research model used to test our hypotheses. In order to "take advantage of the variations in the variable of interest over time" (Fosu et al. 2016, p. 143), we also consider a panel data approach in the analysis. Following the advanced statistic techniques used in the studies such as Muray and Pajuste (2005), Gao and Zhu et al. (2015) and Fosu et al. (2016), we firstly use Pooled-OLS, FEM and REM to generate appropriate results based on cross-sectional and time series data, which are statistically augmented into panel data; and secondly, one-step GMM is employed to exclude endogenous error in the model. In other words, GMM is used to test the sustainability of the model.

In order to test $\mathrm{H}_{1}$, the firm value is defined as a function of firm size (Size), tangible assets (Tang) and sales growth (Growth) (collectively termed as Controls in the equation). To test $\mathrm{H}_{2}$, leverage $(L e v)$ and other extensions are used for measuring the effects of asymmetric information (Asy) (Fosu et al., 2016). As such, the baseline model can be formulated to:

$$
\text { Value }_{i t}=\alpha_{0}+\lambda_{t}+\beta_{1} \text { Lev }_{i t}+\sum_{2}^{4} \beta_{k} \text { Controls }_{k i t}+\gamma A s y_{i t}+\varepsilon_{i t} \text { (Eq.1) }
$$

Which can be further expressed into the three analytic models:

$$
\begin{aligned}
& \text { Value }_{i t}=\alpha_{0}+\lambda_{t}+\beta_{1} \text { Lev }_{i t}+\sum_{2}^{4} \beta_{k} \overrightarrow{\text { Control }}_{k i t}+\beta_{5} \text { AsyDisp (Model 1) (Eq.2) } \\
& \text { Value }_{i t}=\alpha_{0}+\lambda_{t}+\beta_{1} \text { Lev }_{i t}+\sum_{2}^{4} \beta_{k}{\overrightarrow{\text { Control }_{k i t}}}_{\text {- }}+\beta_{5} \text { AsyEr (Model 2) (Eq.3) } \\
& \text { Value }_{i t}=\alpha_{0}+\lambda_{t}+\beta_{1} \text { Lev }_{i t}+\sum_{2}^{4} \beta_{k} \overrightarrow{\text { Control }}_{k i t}+\beta_{5} \text { AsyDummy (Model 3) (Eq.4) }
\end{aligned}
$$


Where $\varepsilon_{i t}$ is the combination error term comprising of firm fixed effect $\mu_{\mathrm{i}}$ and a component assumption being independent and identically distributed $\left(\mathrm{V}_{\mathrm{it}}\right) ; \alpha, \beta, \gamma$ are parameters, subscripts ${ }_{i}$ and ${ }_{t}$ are firm ${ }_{i}$ and time ${ }_{t}, k$ indicates control variables

\section{Results}

\subsection{Descriptive statistics}

To understand the characteristics of our data, a summary of descriptive statistics is disclosed in Table 2.

\section{Insert Table 2 here}

In Table 2, the ratio of average firm value (Value) of our sample firm-year is 0.969 (in Fosu et al., 2016, UK is 1.438$)^{4}$. The average ratio of leverage (Lev) is 0.7146 (the UK is 0.174 ). Annual tangible assets (Tang) account for $46.37 \%$ (the UK is $30.1 \%$ ) the total assets while the total revenue growth reaches $41.17 \%$ (the UK is $12.2 \%$ ) which implies the rapid growth of the firms (however, the minimum figure (-0.9989) suggests some companies are with negative sale growth). The average values of the two variables representing asymmetric information (AsyDisp and Asy-Er) are 0.7824 and 0.7418 respectively (the UK are 0.193 and 0.262 ). The mean value of the third variable for the asymmetric information (Asy-Dummy) is 0.2272 (the UK is 0.503 ) which shows that for almost one-fifth of the observed firm-year data, the dispersion in analysts' forecast is higher than the industry average forecast.

By comparing our results with that in the Fosu et al. (2016) conducted in the UK, we can see there are big differences in terms of information asymmetry and development level between Vietnam and a developed country such as the UK. The leverage rate (0.7146) in Vietnams firms is much higher than that in UK firms (0.174). Putting this result in the tax environment of M\&M theory (Modigliani and Miller, 1963), it indicates UK firms have abundant equity to maintain business.

\subsection{Correlation check}

\footnotetext{
${ }^{4}$ We cite equivalent figures in brackets from a UK study conducted by Fosu et al. (2016) for the purpose of comparison.
} 
Before conducting a regression analysis, multicollinearity among independent variables needs to be examined. We carry out correlation analysis and the correlation matrix is presented in Table 3.

\section{Insert Table 3 here}

It can be seen from the result that the correlation coefficients for all variables in the table are low which suggests the improbability of multicollinearity. We further prove it by testing the Variance Inflation Factor (VIF) and the result shows that all coefficients are less than ten indicating no multicollinearity in the data set (Kennedy, 1992). Table 3 also shows that all of three information asymmetry related variables (i.e. Asy-Disp, Asy-Er and Asy-Dummy) are negatively correlated with firm value (Value), Asy-Disp and Asy-Dummy are also negatively correlated with firm leverage (Lev), and the results preliminarily support our Hypothesis 1.

\subsection{Regression}

Firstly, we run OLS (Ordinary Least Square Pooled -Pooled-OLS) regression for the Model 1, Model 2 and Model 3 formulated in 3.4. The purpose of employing OLS regression is to evaluate the impact of independent variables on dependent ones. The results are shown in Table 4.

\section{Insert Table 4 here}

Reading the results in Table 4, all three variables measuring information asymmetry are not statistically significant. In this case, we decide to apply Fixed-Effect Model (FEM) and Random-Effect Model (REM) to further assess the impact of asymmetric information variables on dependent variables. The results are shown in Table 5.

\section{Insert Table 5 here}

The FEM is used to analyse the correlation between residuals and explanatory variables by controlling and separating the effect of individual characteristics from explanatory variables. Therefore, the real influence of explanatory variables on dependent ones can be estimated accurately. 
According to the regression result in Table 5, most variables representing information asymmetry have a significantly negative impact on the firm value. This means the presence of information asymmetry will lower the firm's value. The regression coefficient of Asy-Disp in REM and FEM ranges is -0.0866 and -0.997 respectively. Additionally, the coefficient also has high statistical significance at 1\% level in the FEM as well as economic significance at which an increase in the standard deviation of Asy-Disp will reduce firm value.

The regression result of $A s y$-Er using FEM and REM in model 2 suggests that the variable has a positive impact on firm value; however, it is not statistically significant. In model 3, the regression coefficient of Asy-Dummy corresponding to REM and FEM values from - 0.3351 to -3.068 and has statistical significance in FEM. It implies that a transition of information asymmetry from low to a high level is associated with a significant reduction in firm value.

Regarding the impact of leverage on enterprise value, the regression result in Table 5 shows the leverage has a positive impact on the firm value, despite the magnitude is quite small. However, the coefficient is not statically significant.

All other control variables are found statistically significant at less than $1 \%$ level. Specifically, both Size and Growth have negative coefficients at -2.8644 and -0.1555 respectively, suggesting they have a negative impact on dependent variables. The two variables are significant in both statistics and economy which means when Size of a company is large, and Growth of the company is strong to a certain extent, and an increase in size and growth will lead to a reduction in firm value. These findings are consistent with that in the research of Murray and Pajuste (2005). The coefficient of Tang is positive at 2.1135 representing a positive impact on dependent variables. It suggests that tangible assets compensate for the loss of intangible assets for firm value.

We further conduct the Hausman test to select the most suitable model. The result reveals that Hausman p-value in both models is less than 0.05 . Therefore, the null hypothesis (H0) is rejected which means the coefficients estimated by the Random Effect model are not as efficient as the coefficients in the Fixed Effect model. Accordingly, applying the FEM method in all models will bring a more consistent result. 
After verifying homoscedasticity, autocorrelation and endogeneity errors in the models, the one-step GMM method is applied to fix errors presented in the models (1), (2), (3). The main reason to choose one-step GMM rather than system-GMM is to ensure the parsimony theorem of statistics. The result of one-step GMM is reported in Table 6. The results of one-step GMM estimation in Table 6 are similar to what we reported in Tables 4 and 5.

\section{Insert Table 6 here}

All three variables measuring information asymmetry (Asy-Disp, Asy-Er and Asy-Dummy) adversely influence on firm value (Value), indicating a negative relationship between information asymmetry and firm value. As such, the first hypothesis (H1: Information asymmetry in Vietnamese firms is negatively correlated with firm value) has been confirmed. The result broadly is consistent with the findings in other studies mentioned in 2.1.

With regards to firms' financial leverage ( $L e v)$, although the variable is positively correlated with the firm value (Value), it has no statistical significance in all the three models. Due to the insignificant effect of leverage on firm value in our estimation, we can say that in Vietnamese firms, financial leverage can help increase the firm value which in turn offsets or mitigates the negative impact of information asymmetry, however, its role perhaps is limited. The finding thus partially supports the second hypothesis (H2: Financial leverage in Vietnamese firms can reduce the negative impact of information asymmetry on firm value).

In terms of firm size and growth, the findings suggest that Size and Growth have a negative impact of on firm value (Value) and the results are in line with the finding in Murray and Pajuste (2005).

Finally, our result also shows that firms' tangible assets (Tang) positively affect firm value indicating tangible assets can compensate the loss of intangible assets and the finding is also consistent with that in the studies of Muray and Pajuste (2005) and Fosu et al. (2016).

\section{Conclusion}

First, if taking a comparative view to compare our results with a similar study conducted in the UK by Fosu et al. (2016), we can summarise: (1) the firm value of our sample is lower than 
that in the UK; (2) the average leverage for Vietnamese firms is much higher than that in the UK firms; (3) the level of tangible assets for Vietnamese firms is also higher than that in the UK firms; (4) the total revenue growth for Vietnamese firms is much higher than that in the UK firms; and (5) the information asymmetry for Vietnamese firms is much higher than that in the UK firms. This comparison clearly shows a difference between Vietnam as an emerging and developing country and the UK as a developed country. Second, our paper proves, with strong evidence, that information asymmetry in Vietnam has a significant negative effect on firm value. The negative relationship is consistent with other studies mentioned earlier and supports POT and agent cost theories but the extent of the negative effect on firm value in Vietnam is stronger. Third, our results also suggest that despite the financial leverage in Vietnamese firms is high, however, its role in mitigating the negative impact of information asymmetry on firm value is limited, unlike in the UK.

Our study contributes to the existing literature in two-fold: (1) it addresses a less explored area by examining the impact of information asymmetry on firm value in developing countries, particularly in Vietnam - an emerging but catching up the economy. The meaning for carrying out such research is to provide with an impression of how far these developing countries are behind developed countries in terms of the relationship between information asymmetry and firm value. Our finding confirms a negative relationship between asymmetric information and firm value in Vietnam, which shares the similarity with the results in other studies in the literature; (2) in Vietnamese context, firms cannot use the financial leverage to control the level of asymmetric information, whereas in Fosu et al. (2016), the result indicates that the UK firms can take financial leverage as a tool to mitigate the effect of asymmetric information. The reason behind this difference requires a separate study to find out. 


\section{References}

Agarwal, P., O'Hara, M. (2007). Information risk and capital structure. (Available at SSRN 939663).

Akerlof, G.A. (1970). The market for 'Lemons': Quality uncertainty and the market mechanism. The Quarterly Journal of Economics, 84, 488-500.

Besbes, L., Boujelbene, Y. (2014). Information asymmetry within financial markets and corporate financing decisions. International Journal of Economics, Finance and Management, $3(2), 50-58$.

Bharath, S. T., Pasquariello, P., Wu, G. (2009). Does asymmetric information drive capital structure decisions? The Review of Financial Studies, 22(8), 3211-3243.

Botosan, C. A. (1997). Disclosure level and the cost of equity capital. Accounting Review, 323-349.

Danso, A., Adomako, S. (2014). The financing behaviour of firms and financial crisis. Managerial Finance, 40 (12), 1159-1174.

Dierkens, N. (1991). Information asymmetry and equity issues. Journal of Financial and Quantitative Analysis, 26, 181-199.

D'Mello, R., Ferris, S. P. (2000). The information effects of analyst activity at the announcement of new equity issues. Financial Management, 29 (1),78-95.

D’Mello, R., Krishnaswami, S., Larkin, P. J. (2008). Determinants of corporate cash holdings: Evidence from spin-offs. Journal of Banking \& Finance, 32(7), 1209-1220.

Drobetz, W., Grüninger, M. C., Hirschvogl, S. (2010). Information asymmetry and the value of cash. Journal of Banking \& Finance, 34(9), 2168-2184.

Fosu, S. (2013). Capital structure, product market competition and firm performance: Evidence from South Africa. The Quarterly Review of Economics and Finance, 53(2),140-151.

Fosu, S., Danso, A., Ahmad, W., Coffie, W. (2016). Information asymmetry, leverage and firm value: Do crisis and growth matter? International Review of Financial Analysis, 46, 140-150.

Gao, W., Zhu, F. (2015). Information asymmetry and capital structure around the world. Pacific-Basin Finance Journal 32, 131-159.

Grossman, S. J., Hart, O. D. (1982). Corporate financial structure and managerial incentives. The Economics of Information and Uncertainty, McCall, J.J. (ed.), University of Chicago Press.

He, W. P., Lepone, A., Leung, H. (2013). Information asymmetry and the cost of equity capital. International Review of Economics and Finance, 27, 611-620.

Kennedy, P. (1992). A Guide to Econometrics, 3d ed. Cambridge, MA: The MIT Press.

Krishnaswami, S., Subramaniam, V. (1999). Information asymmetry, valuation, and the corporate spin-off decision. Journal of Financial economics, 53(1), 73-112.

Krishnaswami, S., Spindt, P. A., Subramaniam, V. (1999). Information asymmetry, monitoring, and the placement structure of corporate debt. Journal of Financial Economics, 51(3), 407-434. 
Maury, B., Pajuste, A. (2005). Multiple large shareholders and firm value. Journal of Banking \& Finance, 29, 1813-1834.

Myers, S.C. (1984). Capital structure puzzle. Journal of Finance, 39(3), 575- 592.

Myers, S. C., Majluf, N. S. (1984). Corporate financing and investment decisions when firms have information that investors do not have. Journal of Financial Economics, 13, 187-221.

Opler, T. C., Titman, S. (1994). Financial distress and corporate performance. Journal of Finance, 49(3), 1015-1040.

Ryen, T. G., Vasconcellos, M. G., Kish, J. R. (1997). Capital structure decisions: What have we learned? Business Horizons, 40(5), 41-50.

Spence A (1973). Job market signalling. The Quarterly Journal of Economics, 87, 355-374.

Stiglitz J.E (1974). Incentives and risk sharing in sharecropping. Review of Economic Studies, $41,219-255$. 
Information Asymmetry and firm value: Is Vietnam different?

Tables

Table 1 Summary of variables

\begin{tabular}{|c|c|c|c|}
\hline Variable & Measurement & Expected sign & Reference \\
\hline Asy-Disp & Dispersion of analysts' forecasts & - & Drobetz et al. (2010), Fosu et al. (2016) \\
\hline$A s y-E r$ & Error analysts' forecast & - & Drobetz et al. (2010), Fosu et al. (2016) \\
\hline Asy-Dummy & $\begin{array}{l}1 \text {, if the dispersion of analysts' forecasts } \\
\text { is greater than the industry average } \\
\text { forecast; otherwise } 0 .\end{array}$ & - & Drobetz et al. (2010), Fosu et al. (2016) \\
\hline Value & $\begin{array}{l}\text { The ratio of market value of assets to } \\
\text { book value of assets }\end{array}$ & & $\begin{array}{l}\text { Muray and Pajuste (2005), Fosu et al. } \\
\text { (2016) }\end{array}$ \\
\hline Lev & $\begin{array}{l}\text { The ratio of book value of debts to book } \\
\text { value of assets }\end{array}$ & $+/-$ & $\begin{array}{l}\text { Danso and Adomako (2014), Fosu } \\
\text { (2013), Opler and Titman (1994), Fosu } \\
\text { et al. (2016) }\end{array}$ \\
\hline Size & $\begin{array}{l}\text { The natural logarithm of the book value } \\
\text { of total assets }\end{array}$ & - & $\begin{array}{l}\text { Muray and Pajuste (2005), Fosu et al. } \\
\text { (2016) }\end{array}$ \\
\hline Tang & The ratio of tangible assets to total assets & $+/-$ & $\begin{array}{l}\text { Muray and Pajuste (2005), Fosu et al. } \\
\text { (2016) }\end{array}$ \\
\hline Growth & The annual growth rate of a firm' sales & + & $\begin{array}{l}\text { Muray and Pajuste (2005), Fosu et al. } \\
(2016)\end{array}$ \\
\hline
\end{tabular}

Table 2 Descriptive statistics

\begin{tabular}{lcccc}
\hline Variable & Mean & Std. Dev & Min & Max \\
\hline Value & 0.9690 & 16.6948 & 0 & 6.1358 \\
Lev & 0.7146 & 11.48497 & 0 & 5.7447 \\
Size & 27.6470 & 1.2889 & 19.4431 & 32.8926 \\
Growth & 0.4117 & 3.1215 & -0.9989 & 0.8825 \\
Tang & 0.4637 & 6.8277 & 0 & 2.6711 \\
Asy-Disp & 0.7824 & 0.8641 & 0 & 7.1621 \\
Asy-Er & 0.7418 & 0.8575 & 0 & 7.7140 \\
Asy-Dummy & 0.2272 & 0.4191 & 0 & 1 \\
\hline Ne:Vari & & & & \\
\hline
\end{tabular}

Note: Variable observations are 2500 
Table 3 Correlation matrix

\begin{tabular}{lcccccccc}
\hline & Value & Lev & Size & Growth & Tang & Asy-Disp & Asy-Dummy & Asy-Er \\
\hline Value & 1.0000 & & & & & & & \\
Lev & -0.0004 & 1.0000 & & & & & & \\
Size & -0.1639 & 0.0163 & 1.0000 & & & & & \\
Growth & -0.0027 & -0.0020 & 0.0169 & 1.0000 & & & & \\
Tang & 0.8904 & -0.0016 & -0.1392 & -0.0090 & 1.0000 & & & \\
Asy-Disp & -0.0118 & -0.0057 & 0.0823 & 0.1002 & -0.0052 & 1.0000 & & \\
Asy-Dummy & -0.0228 & -0.0107 & -0.0265 & 0.0708 & -0.0180 & 0.6738 & 1.0000 & \\
Asy-Er & -0.0047 & 0.0009 & -0.0085 & 0.0969 & -0.0130 & 0.6399 & 0.4797 & 1.0000 \\
\hline
\end{tabular}

Table 4 OLS regression

\begin{tabular}{|c|c|c|c|}
\hline Variable & Model (1) & Model (2) & Model (3) \\
\hline \multirow{2}{*}{ Lev } & 0.0024 & 0.0024 & 0.0023 \\
\hline & $(0.0131)$ & $(0.0132)$ & $(0.0132)$ \\
\hline \multirow{2}{*}{ Size } & $-0.5249 * * *$ & $-0.5287 * * *$ & $-0.5330 * * *$ \\
\hline & $(0.1191)$ & $(0.1187)$ & $(0.1187)$ \\
\hline \multirow{2}{*}{ Growth } & 0.0342 & 0.0288 & 0.0351 \\
\hline & $(0.0487)$ & $(0.0487)$ & $(0.0486)$ \\
\hline \multirow{2}{*}{ Tang } & $2.1634 * * *$ & $2.1635^{* * *}$ & $2.1629 * * *$ \\
\hline & $(0.0224)$ & $(0.0224)$ & $(0.0224)$ \\
\hline \multirow{2}{*}{ Asy-Disp } & -0.0866 & & \\
\hline & $(0.1768)$ & & \\
\hline \multirow{2}{*}{$A s y-E r$} & & 0.1157 & \\
\hline & & $(0.1775)$ & \\
\hline \multirow{2}{*}{ Asy-Dummy } & & & -0.3351 \\
\hline & & & $(0.3626)$ \\
\hline \multirow{2}{*}{ Cons } & $14.5309 * * *$ & $14.4851 * * *$ & $14.7625 * * *$ \\
\hline & $(3.2902)$ & $(3.2918)$ & $(3.2922)$ \\
\hline
\end{tabular}

Note: ***,** and * are the significance levels of $1 \%, 5 \%$ and $10 \%$ respectively 
Table 5 FEM and REM regression

\begin{tabular}{|c|c|c|c|c|c|c|}
\hline \multirow{2}{*}{ Variable } & \multicolumn{2}{|c|}{ Model 1} & \multicolumn{2}{|c|}{ Model 2} & \multicolumn{2}{|c|}{ Model 3} \\
\hline & FE & $\mathbf{R E}$ & $\mathbf{F E}$ & RE & FE & $\mathbf{R E}$ \\
\hline Lev & $\begin{array}{c}0.0073 \\
{[0.0136]}\end{array}$ & $\begin{array}{c}0.0024 \\
{[0.0132]}\end{array}$ & $\begin{array}{c}0.0066 \\
{[0.0136]}\end{array}$ & $\begin{array}{l}0.00245 \\
{[0.0132]}\end{array}$ & $\begin{array}{c}0.0066 \\
{[0.0136]}\end{array}$ & $\begin{array}{c}0.0023 \\
{[0.0132]}\end{array}$ \\
\hline Size & $\begin{array}{c}-2.8644 * * * \\
{[0.2851]}\end{array}$ & $\begin{array}{c}-0.5249 * * * \\
{[0.1191]}\end{array}$ & $\begin{array}{c}-2.7900 * * * \\
{[0.2857]}\end{array}$ & $\begin{array}{c}-0.5288 * * * \\
{[0.1187]}\end{array}$ & $\begin{array}{c}-2.8017 * * * \\
{[0.2838]}\end{array}$ & $\begin{array}{c}-0.5330 * * * \\
{[0.1188]}\end{array}$ \\
\hline Growth & $\begin{array}{c}-0.1555^{* * *} \\
{[0.0503]}\end{array}$ & $\begin{array}{c}0.0342 \\
{[0.0488]}\end{array}$ & $\begin{array}{c}-0.1590 * * * \\
{[0.0505]}\end{array}$ & $\begin{array}{c}0.0288 \\
{[0.0488]}\end{array}$ & $\begin{array}{c}-0.1553 * * * \\
{[0.0503]}\end{array}$ & $\begin{array}{c}0.0351 \\
{[0.0487]}\end{array}$ \\
\hline Tang & $\begin{array}{c}2.1135 * * * \\
{[0.0240]}\end{array}$ & $\begin{array}{c}2.1635^{* * *} \\
{[0.0224]}\end{array}$ & $\begin{array}{c}2.1144 * * * \\
{[0.0241]}\end{array}$ & $\begin{array}{c}2.1635^{* * *} \\
{[0.0224]}\end{array}$ & $\begin{array}{c}2.1141 * * * \\
{[0.0240]}\end{array}$ & $\begin{array}{c}2.163 * * * \\
{[0.0224]}\end{array}$ \\
\hline Asy-Disp & $\begin{array}{c}-0.9970 * * * \\
{[0.3686]}\end{array}$ & $\begin{array}{c}-0.0866 \\
{[0.1768]}\end{array}$ & & & & \\
\hline$A s y-E r$ & & & $\begin{array}{c}0.1351 \\
{[0.2354]}\end{array}$ & $\begin{array}{c}0.1157 \\
{[0.1776]}\end{array}$ & & \\
\hline Asy-Dummy & & & & & $\begin{array}{c}-3.0682 * * * \\
{[0.7991]}\end{array}$ & $\begin{array}{c}-0.3351 \\
{[0.3627]}\end{array}$ \\
\hline Cons & $\begin{array}{c}80.0225 * * * \\
{[7.9167]}\end{array}$ & $\begin{array}{c}14.5309 * * * \\
{[3.2902]}\end{array}$ & & & $\begin{array}{c}78.2037 * * * \\
{[7.8534]}\end{array}$ & $\begin{array}{c}14.7625^{* * *} \\
{[3.2922]}\end{array}$ \\
\hline
\end{tabular}


Table 6 GMM regression

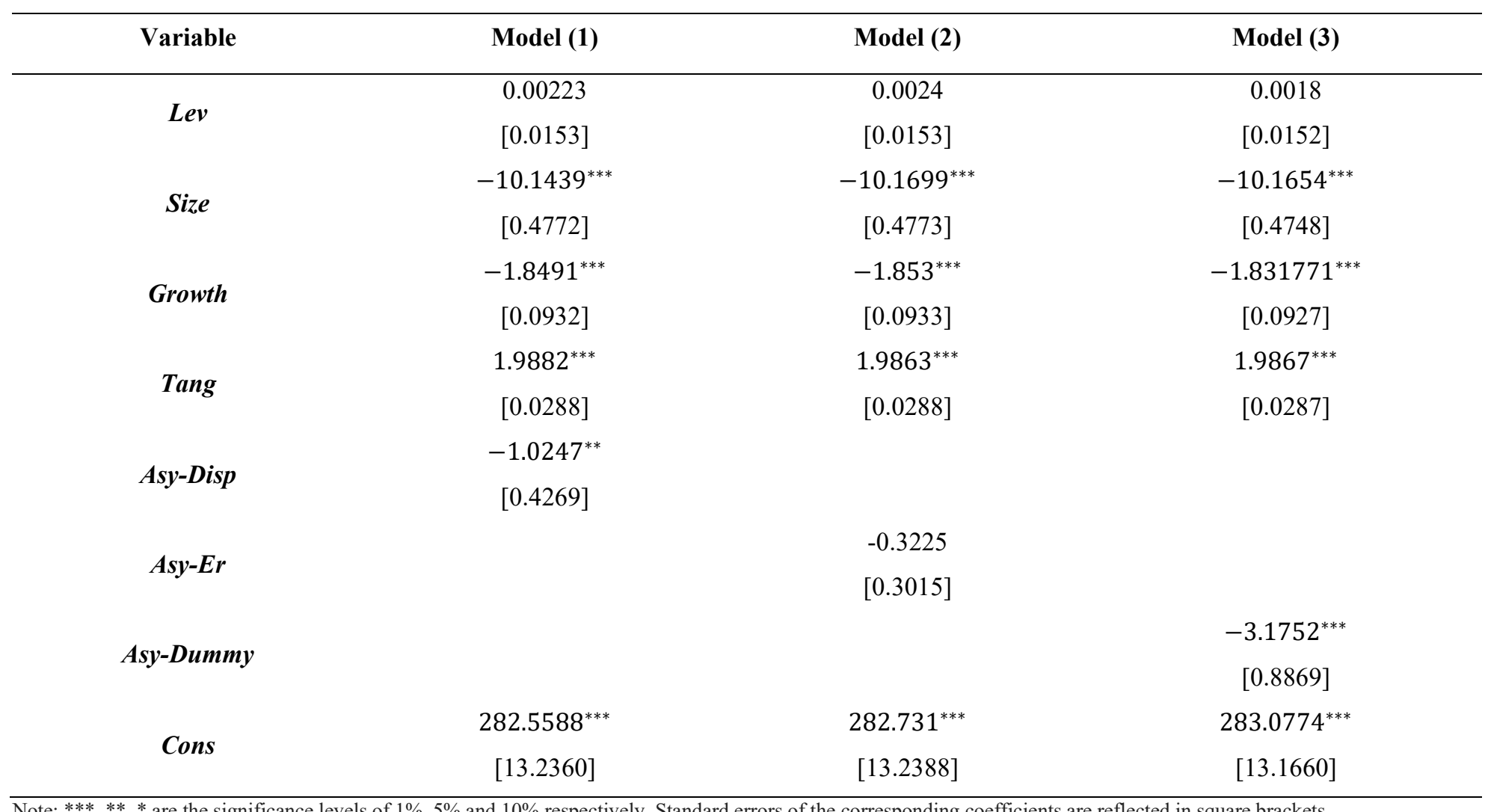

Note: $* * *, * * *$ are the significance levels of $1 \%, 5 \%$ and $10 \%$ respectively. Standard errors of the corresponding coefficients are reflected in square brackets. 